\title{
HUBUNGAN KEUNTUNGAN DENGAN RESIKO DALAM PERSPEKTIF FIQIH APLIKASINYA PADA INSTITUSI KEUANGAN ISLAM
}

\author{
Eka Nuraini Rachmawati ${ }^{1}$ \& Ab Mumin bn Ab Ghani ${ }^{2}$ \\ ${ }^{1}$ Fakultas Ekonomi (FE), Universitas Islam Riau (UIR) \\ ${ }^{2}$ Akademi Pengajian Islam, University of Malaya (UM) \\ Email: ekanura212@yahoo.co.id
}

\begin{abstract}
ABSTRAK
Tujuan berinvestasi adalah mengharapkan keuntungan dimasa yang akan datang. Namun untuk memperoleh keuntungan pelaku bisnis atau investor harus menghadapi resiko dari investasi tersebut, karena pada dasarnya keuntungan dan resiko memiliki hubungan yang searah dan linier. Artikel ini membahas konsep keuntungan, rugi dan resiko dalam perspektif Islam. Selanjutnya, menjelaskan jenis-jenis resiko yang dihadapi institusi keuangan Islam serta untuk mengetahui berlakukah prinsip "high risk high return" atau "al ghurm bi al ghunm" pada institusi keuangan Islam.
\end{abstract}

Kata kunci : Keuntungan, Risiko, Investasi.

\begin{abstract}
The aim of investment is to expect a return in future. But to obtain a return, the investor must face a risk from the investment because risk and return have positive and linier relationship. This article describe return and risk based on Islamic financial institution and to find out the implementation of "al ghurm bi al ghunm" (high risk high return) principle in Islamic financial institution.
\end{abstract}

Keywords : Return, Risk, Invesment. 


\section{PENDAHULUAN}

Bagi pelaku bisnis atau investor
terdapat dua pilihan $r$ dalam
menginvestasikan dananya,
investasi pada sektor riil atau sektor
keuangan. Berinvestasi pada sektor
keuangan memiliki resiko lebih rendah
dari pada sektor riil, karena investor
dengan mudah akses ke pasar keuangan.
Jika pilihan investasinya pada sektor
keuangan, maka investor dapat
menginvestasikan dananya pada pasar
uang (money market) atau pasar modal
(capital market).

Perbedaan antara kedua pasar keuangan tersebut terletak pada jenis produk dan jangka waktu investasi. Pada pasar uang, produk yang ditawarkan memiliki jangka waktu kurang dari satu tahun, sedangkan pada pasar modal produk yang ditawarkan berupa surat berharga, seperti saham dan obligasi yang memiliki jangka waktu lebih dari satu tahun. Investor akan memilih instrumen keuangan yang sesuai dengan tujuan investasinya, artinya ketika tujuan investasinya untuk jangka panjang maka dia harus memilih instrumen pasar modal.

Keuntungan dan resiko merupakan masalah penting bagi investor dan pelaku bisnis. Pola hubungan antara keuntungan dan resiko antar instrumen harus dipahami terlebih dahulu, supaya dapat memilih investasi yang terbaik. Hal ini disebabkan keputusan investasi akan sangat tergantung seberapa besar keuntungan yang akan diperoleh dan besarnya resiko yang harus ditanggung oleh pelaku bisnis atau investor. Investor akan memilih investasi yang menghasilkan keuntungan yang tinggi dengan resiko yang relatif rendah, baik investasi pada institusi keuangan konvensional maupun institusi keuangan Islam.

\section{TINJAUAN PUSTAKA}

\section{Keuntungan dalam Perspektif Islam}

Tujuan investor atau pelaku bisnis melakukan investasi adalah mengharapkan keuntungan di masa yang akan datang. Keuntungan tersebut di hasilkan dari perputaran modal, yaitu selisih harga jual dengan harga beli barang atau keuntungan yang berasal dari pengurangan total penjualan (total revenue) dengan total biaya (total cost).

Banyak istilah yang digunakan untuk menunjukkan keuntungan atau laba, yakni profit, yield atau return. Walaupun semua istilah tersebut mengacu pada laba, namun istilah return sering digunakan sebagai ukuran imbal hasil saham sedangkan yield sebagai ukuran imbal hasil obligasi baik obligasi konvensional maupun obligasi syariah (sukuk).

\section{Konsep dan Istilah Laba dalam Islam}

Laba berasal dari proses pemutaran modal dan aktivitas perdagangan, serta aktivitas investasi. Laba menunjukkan ada pertambahan harta atau modal awal yang digunakan dalam perdagangan atau investasi.

Dalam konsep Islam, keuntungan atau laba dapat dikaitkan dengan beberapa istilah, yaitu, nama', ar-ribh, al-ghallah dan al-faidah. Nama' (نماء) dalam bahasa Arab (لناما), diartikan sebagai berkembang, berbunga atau pertumbuhan, makin tumbuh, makin besar. Nama' (نماء) dimaksudkan sebagai pertumbuhan pada pendapatan atau pada harta dalam jangka waktu tertentu.

Menurut ulama fikih, nama, dibagi menjadi dua macam, yaitu: nama' khalqi (pertumbuhan alami) yang tidak ada campur tangan manusia sama sekali, seperti pertambahan pada emas, perak, dan barang-barang milik.

Kedua, nama' fi'liy (perkembangan buatan), yaitu campur tangan manusia, seperti dalam perdagangan, industri, pertanian karena adanya proses tukar-menukar dan 
interaksi serta menghadapi hal-hal yang beresiko.

Dilihat dari aspek hubungan dengan asal harta, ulama fikih membagi nama' menjadi dua. Pertama, nama' yang terpisah dari asal (pokok) seperti hasil dari binatang ternak. Kedua nama' yang saling berhubungan, seperti pertambahan dalam harta dagang.

Ulama fikih Malikiyah membagi nama' dari aspek sifatnya, menjadi: laba, ghallah dan faidah (فائدة). Dalam bahasa Arab, al-ghallah (الغالة) memiliki arti memahalkan, dan al-faidah (الفائدة) artinya untung sedangkan al-ribh (الربح) bermakna keuntungan.

Adapun makna dari kata al-faidah, al-ghallah dan al-ribh menurut Syhatah (2001) sebagai berikut:

Al-faidah (الفائدة) adalah laba yang berasal dari modal pokok. Pertambahan pada barang milik (asal modal pokok) yang ditandai dengan perbedaan antara harga pembelian dengan harga penjualan.

Al-ghallah (الغالة) adalah laba yang timbul dengan sendirinya atau insidental. Pertambahan terdapat pada barang dagangan sebelum penjualan, seperti wol atau susu dari hewan yang akan dijual.

Al-ribh (الربح) adalah keuntungan atau laba. Dalam akuntansi laba berasal dari selisih antara pendapatan dengan biaya. Al-ribh al-Tijari merupakan laba yang berasal dari aktivitas perdagangan.

\section{Laba Menurut al-Qur'an}

Konsep laba dalam Al-Qur'an terdapat dala surah Al-Baqarah ayat 16, Allah SWT berfirman :

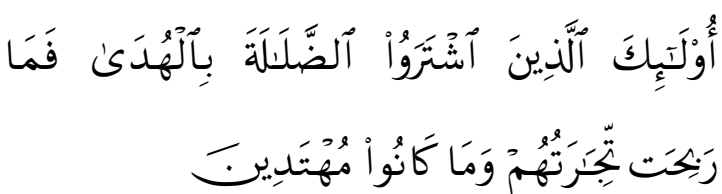

Artinya : Mereka itulah orang yang membeli kesesatan dengan petunjuk, maka tidaklah beruntung perniagaan mereka dan tidaklah mereka mendapat pertunjuk. (Q.S. Al-Baqarah [2]:16).

Maksud ayat diatas, mereka menjual petunjuk untuk mendapat kesesatan, hal ini juga berlaku juga pada orang yang pernah beriman lalu kembali kepada kekufuran, karena lebih menyukai kesesatan daripada petunjuk. Perniagaan yang mereka lakukan itu tidak mendapat keuntungan dan tidak pula mereka mendapat petunjuk pada apa yang mereka lakukan.

\section{Konsep laba dalam Hadis}

Konsep laba dalam hadis, terdapat pada Hadis Riwayat Bukhari dan Muslim: "Seorang mu'min itu bagaikan seorang pedagang, dia tidak akan menerima laba sebelum ia mendapatkan modal pokoknya. Demikian, juga seorang mu'min tidak akan mendapat amalan-amalan sunnahnya sebelum ia menerima amalan wajibnya".

\section{Konsep Laba menurut Ulama Fikih}

Menurut Ibn Qudamah, "Laba dari harta dagangan ialah pertumbuhan pada modal, yaitu pertambahan nilai barang dagangan. Selanjutnya, Ibn Al-Arabi berkata, setiap mu'awadhah (barter) merupakan perdagangan terhadap apapun bentuk barang penggantinya. Konsep laba disini menunjukkan bahwa laba adalah hasil dari selisih nilai awal harga pembelian dengan nilai penjualan. (Syhatah dan Fayyadh, 2004)

Di dalam kitab Muqaddimah Ibn Khaldun dikatakan, "perdagangan ialah usaha untuk mewujudkan pertumbuhan atau pertambahan harta dengan membeli barang dengan murah kemudian menjualnya kembali dengan harga mahal. Apapun jenis barangnya, jumlah pertambahan itulah yang disebut laba. Lebih khusus lagi bahwa perdagangan 
adalah membeli barang dagangan dan harta benda, serta menyimpan, menunggu hingga perkembangan pasar membawa kenaikan harga, sehingga menghasilkan keuntungan.

Laba menurut Imam Ghazali sebagaimana dikutip oleh Ahmad Ifham Sholihin adalah keuntungan yang berasal dari kompensasi dari kesulitan perjalanan, resiko bisnis dan ancaman keselamatan dari pengusaha, sehingga sangat wajar seseorang memperoleh keuntungan yang merupakan kompensasi dari resiko yang ditanggungnya. (Sholihin, 2002).

Beberapa definisi laba diatas, disimpulkan bahwa laba merupakan pertambahan harta dari modal pokok karena kenaikan harga yang menyebabkan penjualan lebih tinggi dari pembelian dan sebagai konpensasi dari resiko yang ditanggung pelaku bisnis.

\section{Pengukuran Laba dalam Islam}

Pengertian laba secara bahasa serta menurut Al-Qur'an, Sunnah, dan pendapat ulama-ulama fikih seperti yang dijelaskan di atas dapat disimpulkan bahwa laba adalah pertambahan pada modal pokok perdagangan atau dapat juga dikatakan sebagai tambahan nilai yang timbul karena perdagangan.

Beberapa aturan tentang laba dalam konsep Islam (Syhatah dan Fayyadh, 2004) :

1. Adanya harta (uang) yang dikhususkan untuk perdagangan.

2. Mengoperasikan modal tersebut secara interaktif dengan unsur-unsur lain yang terkait untuk produksi, seperti usaha dan sumber-sumber alam.

3. Mempromosikan harta sebagai objek dalam pemutarannya karena adanya kemungkinan-kemungkinan

pertambahan atau pengurangan jumlahnya.
4. Selamatnya modal pokok yang berarti modal bisa dikembalikan.

Besar kecilnya laba yang diperoleh pedagang tergantung pada besaran harga pokok serta biaya yang dikeluarkan untuk membuat suatu produk. Untuk mengetahui besarnya laba yang akan diperoleh pedagang, maka perlu pengukuran, yaitu :

\section{Taqlib dan Mukhatarah (Interaksi dan resiko)}

Laba adalah hasil dari perputaran modal melalui transaksi bisnis, seperti menjual dan membeli, atau jenis-jenis apapun yang dibolehkan oleh syariah.

Dalam pelaksanaannya terdapat kemungkinan resiko yang terjadi pada modal yang nantinya akan menimbulkan pengurangan modal pada suatu putaran dan pertambahan pada putaran lain. Jadi tidak boleh menjamin pemberian laba pada aktivitas dengan akad mudarabah dan musharakah.

Hal ini ditegaskan oleh ulama fikih dengan mengatakan bahwa perdagangan ialah perputaran modal dengan bentuk tukar menukar barang (barter) dan unsur-unsur bentuk resiko, sehingga jika terjadi perbedaan laba karena faktor perbedaan unsur taqlib dan mukhatarah.

\section{Al-Muqabalah}

Menunjukkan perbandingan jumlah hak milik pada awal periode yang sama atau dengan membandingkan nilai barang yang ada pada akhir periode itu dengan nilai barang yang ada pada awal periode yang sama. Juga dapat membandingkan pendapatan dengan biaya-biaya yang dikeluarkan untuk memperoleh pendapatan.

Pendapatan harus halal dan baik, biaya pun harus resmi dan jelas serta tidak mengandung unsur-unsur yang terlarang dalam syara', seperti riba, gharar, maysir, suap dan mubazir. 


\section{Keutuhan Modal Pokok}

Laba tidak akan tercapai kecuali setelah utuhnya modal pokok dari segi kemampuan secara ekonomi sebagai alat penukar barang yang dimiliki sejak awal aktivitas ekonomi. Menurut Imam Qurtubi, "Seseorang pedagang yang berhasil ialah orang yang dapat menukarkan barang yang ia miliki dengan suatu pengganti (barang lain) yang lebih bernilai atau lebih tinggi harganya dari barang yang pertama".

Imam al-Nasafi berkata, "Tuntunan dagang ialah keselamatan dan keutuhan modal pokok serta mendapat laba. Orang yang tidak mendapatkan modalnya kembali maka ia tidak dapat dikatakan beruntung".

\section{Laba dari Produksi}

Pertambahan yang terjadi pada harta selama setahun dari semua aktivitas penjualan dan pembelian, atau memproduksi dan menjual, yaitu dengan pergantian barang menjadi uang dan pergantian uang dengan barang, maka barang yang belum terjual pada akhir tahun juga mencakup pertambahan yang menunjukkan perbedaan antara harga yang pertama dan nilai atau harga yang sedang terjadi. Berdasarkan nilai ini, ada dua macam laba yang terdapat pada akhir tahun, yaitu laba yang berasal dari proses jual beli dalam setahun dan laba tambahan, baik yang taqdiri (nyata) maupun yang hukmi (abstrak) karena barang-barangnya belum terjual.

Shauqi Shayatah menyatakan bahwa, "Pandangan fikih akuntansi Islam dalam sistem pengukuran laba adalah sama, yaitu nama' (pertambahan, pertumbuhan, makin tumbuh, makin besar) dan laba berasal dari kekuatan atau usaha. Jadi pengukuran laba menurut fikih adalah bertambahnya harta pokok atau modal awal yang berasal dari kenaikan harga atau proses perputaran modal.

\section{Resiko dalam Perspektif Islam}

Dalam kehidupan sehari-hari, kata resiko selalu digunakan oleh pelaku bisnis, sebab kata resiko ini berhubungan dengan keuntungan suatu investasi. Istilah resiko berasal dari bahasa Itali iaitu risco yang memiliki arti bahaya. Resiko memiliki banyak definisi, salah satu definisi resiko adalah kemungkinan mengalami kerugian atau bahaya.

Definisi lain, resiko adalah kerugian karena peristiwa yang tidak diharapkan terjadi. (T. Sunaryo, 2007)

Menurut konsep keuangan bahwa resiko merupakan perbedaan antara keuntungan atau imbal hasil yang terealisasi (actual return) dengan keuntungan atau imbal hasil yang diharapkan (expected return) dalam suatu investasi.

Resiko ini terjadi jika keuntungan yang terealisasi lebih kecil daripada keuntungan yang diharapkan. (Tandelilin, 2012) Semakin besar perbedaan antar tingkat keuntungan tersebut maka semakin besarlah resikonya.

Resiko dalam Islam dikenal dengan istilah Mukhatarah (مخاطرة ) dalam bahasa Arab. Mukhatarah ini berasal dari kata al- khatar (الخطر ). Alkhatar yaitu sesuatu yang tidak diketahui pasti benar atau tidaknya atau sesuatu yang mengandung bahaya. Dalam kamus bahasa Arab, mukhatharah (خاطرة) memiliki arti menempuh bahaya atau menyerempet bahaya.

Resiko dalam berinvestasi di Pasar Modal, dibedakan menjadi dua kelompok, yaitu resiko sistematik dan resiko tidak sistematik. Resiko sistematik (systematic risk) merupakan resiko yang bersumber daripada variabel makro ekonomi, sehingga tidak dapat dihilangkan walaupun melalui diversifikasi, maka disebut non diversifible risk. Adapun resiko tidak sistematik (unsystematic risk) 
resiko yang ditimbulkan oleh perbedaan keunikan perusahaan atau karakteristik perusahaan, yaitu aspek pasar, aspek bahan baku, aspek manajemen dan aspek lainnya. Resiko ini dapat dihilangkan dengan diversifikasi saham yang dibeli investor.

\section{Jenis Resiko dalam Keuangan Syariah}

Pada dasarnya jenis resiko yang terdapat dalam keuangan konvensional hampir sama dengan resiko yang dihadapi keuangan syariah. Menurut Dusuki (2009), resiko dapat dikelompokkan menjadi tiga kategori, yaitu : resiko yang diharamkan (Prohibited Risk), resiko yang harus ditanggung (Essential Risk), Resiko yang dapat dikendalikan (Permisible Risk).

\section{Jenis Resiko Pada Institusi Keuangan Islam}

Jenis resiko yang dihadapi Institusi Keuangan Islam (Islamic Finance Institution), resiko yang dihadapi Pasar Modal Syariah terutama Perbankan Syariah, dikelompokkan menjadi empat jenis resiko, yaitu: Resiko Keuangan (Financial Risk), Resiko Bisnis (Business Risk), Resiko Treasuri (Treasury Risk) dan Tata Kelola Perusahaan (Governance Risk).

\section{Resiko Finansial (Financial Risk)}

Resiko finansial adalah resiko yang berkaitan dengan keputusan perusahaan untuk menggunakan hutang dalam pembiayaan modalnya, semakin besar hutang yang digunakan perusahaan maka akan semakin besar resiko finansial yang dihadapi perusahan. (Tandelilin, 2010) Resiko finansial (Financial Risk) terbagi tiga, yaitu resiko kredit, resiko pasar dan resiko ekuitas.

\section{- Resiko Kredit (Credit Risk)}

Resiko kredit adalah resiko yang disebabkan pihak peminjam tidak dapat melunasi kewajibannya kepada bank untuk membayar angsuran pokok ataupun margin sebagaimana yang telah disepakati dalam perjanjian pembiayaan. Hal ini pada akhirnya akan menimbulkan kredit macet. (M. Hanafi, 2006) Pada pasar modal, resiko kredit terjadinya disebabkan penerbit gagal membayar (default) yield atau imbal hasil sukuk kepada investor ketika jatuh tempo.

\section{- Resiko Pasar (Market Risk)}

\section{Resiko pasar terjadi harga} bergerak kearah yang tidak menguntungkan sehingga merugikan investor dan pelaku bisnis. Resiko pasar ini muncul karena pergerakan harga yang tidak diharapkan akibat penurunan yield (imbal hasil) pada sukuk dan saham, peringkat benchmark (LIBOR), perubahan nilai tukar valuta asing, serta perubahan harga komoditas.

Resiko pasar ini masih dibagi menjadi tiga jenis resiko (Iqbal, Zamir dan Mirakhor, 2006), yakni resiko mark-up, resiko nilai tukar mata uang serta resiko harga (price risk) aset maupun ekuitas.

\section{- Resiko Investasi Ekuitas (Equity Investment Risk)}

Resiko investasi ekuitas merupakan resiko akibat bank ikut menanggung kerugian usaha nasabah yang dibiayai dalam pembiayaan bagi hasil berbasis profit and loss sharing seperti pembiayaan mudharabah dan musyarakah. Resiko investasi ekuitas terjadi pada bank syariah ketika berinvestasi pada instrumen pasar modal syariah seperti saham, sukuk maupun reksadana syariah dan mengalami kerugian akibat penurunan harga instrumen pasar modal tersebut. (Iqbal, Zamir dan Mirakhor, 2006)

\section{Resiko Bisnis (Business Risk)}

Resiko bisnis dikaitkan dengan lingkungan bisnis perbankan, termasuk faktor variabel makro ekonomi, kebijakan, faktor legal dan regulasi, serta 
infrastruktur sektor perbankan. Resiko bisnis juga mencakup ketidakcukupan modal dan ketidakmampuan membayar hutang (insolvency).

Resiko Bisnis (Business Risk) terdiri dari resiko tingkat imbal hasil (Rate of Return Risk), resiko penarikan (displaced financial risk), dan resiko likuiditas (solvency risk).

- Resiko Tingkat Imbal Hasil (Rate of Return Risk)

Resiko tingkat pengembalian bersumber dari ketidakpastian bank dalam memperoleh keuntungan. Ketidakpastian ini dapat menyebabkan tidak tercapainya ekspektasi pemilik rekening terhadap sisi hutang, semakin besar perbedaan semakin besar resiko tingkat pengembalian. Resiko ini terjadi akibat perubahan tingkat imbal hasil yang dibayarkan bank kepada nasabah, karena terjadi perubahan tingkat imbal hasil bank syariah yang diterima dari kontrak pembiayaan.

\section{- Displaced Commercial Risk}

Merupakan transfer resiko yang berkaitan dengan simpanan kepada pemegang saham. Resiko ini muncul ketika bank berada dibawah tekanan untuk mendapat profit, namun bank memberikan sebagian profitnya kepada deposan karena rendahnya imbal hasil yang diterima deposan.

\section{- Resiko Penarikan (Withdrawal Risk)}

Resiko ini bersumber dari tekanan kompetitif yang dihadapi bank syariah dari bank konvensional sebagai counterpart-nya. Bank syariah mengahadapi resiko penarikan dana (withdrawal risk) ketika nasabah menerima imbal hasil (return) dari bank syariah lebih rendah dari return yang diberikan oleh bank pesaingnya.

\section{- Resiko Liquiditas (Liquidity Risk)}

Resiko likuiditas merupakan resiko yang dihadapi perbankan karena tidak dapat memenuhi kebutuhan kas untuk membayar kewajiban jangka pendek. Hal ini disebabkan, turunnya kepercayaan nasabah terhadap sistem perbankan, ketergantungan pada sekelompok deposan, misalnya pemilik deposito mudharabah dapat menarik dananya kapan saja, tanpa pemberitahuan terlebih dahulu, mismatching antara dana jangka pendek dengan pembiayaan jangka panjang, keterbatasan instrumen keuangan untuk solusi likuiditas, karena bank syariah hanya memiliki instrumen Sertifikat Bank Indonesia Syariah (SBIS) dan Pasar Uang antar Bank Syariah.

Pada pasar modal, resiko likuiditas terjadi jika sekuritas seperti sukuk atau saham tidak dapat untuk diperjual belikan secara cepat di pasar sekunder. Hal ini disebabkan sebagian besar investor membeli sekuritas untuk disimpan sampai jatuh tempo. Semakin cepat sekuritas diperjual belikan maka semakin likuid sekuritas tersebut.

\section{Resiko Treasuri (Treasury Risk)}

Resiko Treasuri (Treasury Risk) terdiri dari resiko manajemen liabilitas asset dan resiko lindung nilai (hedging).

- Resiko Manajemen Liabilitas dan Aset (Asset \& Liability Management Risk)

Resiko manajemen liabilitas dan asset merupakan selisih neraca akibat perbedaan jatuh tempo aset dan liabilitas dan komposisi portofolio bank pada sisi aset dan liabilitasnya.

\section{- Resiko Lindung Nilai (Hegding Risk)}

Resiko hedging merupakan resiko kegagalan institusi keuangan syariah untuk meminimalkan dan mengelola berbagai resiko yang ditimbulkan pergerakan nilai tukar dan harga pasar aset. Hal ini disebabkan ketidaktersediaan instrumen hedging yang sesuai syariah, ditambah lagi sekuritas di pasar sekunder tidak likuid. 


\section{Resiko Tata Kelola Perusahaan (Governance Risk )}

Resiko berkaitan dengan Tata Kelola Perusahaan (Governance Risk ) terbagi lima jenis resiko, yaitu resiko operasional, resiko reputasi, resiko transparansi, resiko kepatuhan syariah dan resiko fidusiari. (Iqbal, Zamir dan Mirakhor, 2006)

\section{- Resiko Operasional (Operational Risk)}

Resiko ini berkaitan dengan operasional perbankan syariah, akibat kurangnya sistem informasi dan sistem pengawasan internal serta tidak berfungsi nya proses internal, akibatnya kegiatan operasional bank tidak berjalan lancar sehingga menyebabkan kerugian. Hal ini disebabkan kegagalan sistem, human error, pengendalian dan prosedur yang tidak memenuhi standar yang telah ditetapkan. (M. Hanafi, 2006)

\section{- Resiko Reputasi (Reputation Risk)}

Resiko ini berkaitan menurunnya tingkat kepercayaan nasabah kepada bank syariah yang disebabkan publikasi yang negatif dan persepsi negatif terhadap bank syariah sehingga dapat berpengaruh secara siginifikan pada pangsa pasar bank syariah, profitabilitas dan likuiditas. Untuk meminimalkan resiko reputasi, bank syariah melakukan kolaborasi dengan bank syariah lainnya, standarisasi kontrak, pengujian mandiri dan pembentukan asosiasi industri antar bank syariah. (Iqbal, Zamir dan Mirakhor, 2006)

\section{- Resiko Transparansi (Transparancy Risk)}

Transparansi diartikan sebagai keterbukaan publik terhadap informasi yang lengkap dan akurat serta tepat waktu yang memungkinkan penggunanya melakukan penilaian akurat terhadap kondisi keuangan, aktivitas bisnis, profil bisnis serta manajemen resiko sebuah bank. Resiko tranparansi muncul ketika perbankan kurang terbuka terhadap resiko kerugian akibat pengelolaan dana yang tidak tepat, akibatnya informasi yang dipublikasikan tidak lengkap dan tidak akurat.

\section{- Resiko Kepatuhan Syariah (Shariah Compliance Risk)}

Perkembangan perbankan syariah yang pesat memungkinkan adanya produk yang ditawarkan yang tidak memenuhi aspek syariah atau tidak melaksanakan peraturan perundang-undangan dan ketentuan lain yang berlaku. Hal inilah yang menyebabkan munculnya resiko kepatuhan syariah karena resiko ini berkaitan dengan praktik non standard dalam kontrak. Padahal standarisasi dan perhatian atas aturan-aturan syariah pada institusi keuangan syariah dibuat untuk tujuan melindungi investor muslim dari praktek-praktek yang tidak sesuai dengan prinsip syariah.

\section{- Resiko Fidusiari (Fiduciary Risk)}

Resiko fidusiari adalah resiko yang timbul akibat kegagalan bank untuk bertindak sesuai dengan standar yang telah ditetapkan. Secara hukum bank bertanggung jawab atas pelanggaran kontrak investasi baik ketidaksesuaiannya dengan ketentuan syariah maupun salah kelola (mismanagement) terhadap dana nasabah.

Resiko fidusiari dapat menimbulkan konsekuensi yang serius bagi bank, karena hal tersebut dapat mengakibatkan resiko reputasi yang menciptakan kepanikan dikalangan nasabah, sehingga mereka memutuskan untuk menarik dana mereka. Selain itu, bisa menyebabkan bank terkena sanksi penalti atau kompensasi yang dapat merugikan bank. Selanjutnya, resiko tersebut akan berdampak negatif terhadap harga pasar ekuitas pemegang saham. (Iqbal, Zamir dan Mirakhor, 2006) 
Hasil riset mengenai manajemen resiko pada industri keuangan syariah yang dilakukan oleh Khan dan Habib (2001), menyimpulkan bahwa pembiayaan musyarakah mengahadapi resiko kredit yang paling tinggi dan pembiayaan murabahah menghadapi resiko kredit yang paling rendah. Pembiayaan bay istishna memiliki resiko mark-up paling tinggi dan pembiayaan murabahah yang paling rendah. Pembiyaan musyarakah mutanaqisah menghadapi resiko likuiditas yang paling tinggi dan pembiayaan mudharabah yang paling rendah, Pembiayaan musyarakah mutaqisah juga menghadapi resiko operasional yang paling tinggi dan pembiayaan Ijarah paling rendah resiko operasionalnya. (Khan \& Habib, 2001)

\section{Tabel 1: Resiko Kredit, Resiko Mark-up, Resiko Likuiditas dan Resiko Operasi pada Produk Bank Islam}

\begin{tabular}{lcccc}
\hline Produk & Resiko Kredit & $\begin{array}{c}\text { Resiko } \\
\text { Mark-up }\end{array}$ & $\begin{array}{c}\text { Resiko } \\
\text { Likuiditas }\end{array}$ & $\begin{array}{c}\text { Resiko } \\
\text { Operasional }\end{array}$ \\
\hline $\begin{array}{l}\text { Musyarakah } \\
\begin{array}{l}\text { Musyarakah } \\
\text { Mutanaqisah }\end{array}\end{array}$ & 3.69 & 3.40 & 2.92 & 3.18 \\
\hline Mudarabah & 3.25 & 3.40 & 3.33 & 3.40 \\
\hline Bay Salam & 3.20 & 3.00 & 2.46 & 3.08 \\
\hline Bay Istishna & 3.13 & 3.50 & 3.20 & 3.25 \\
\hline Ijarah & 2.64 & 3.57 & 3.00 & 3.29 \\
\hline Murabahah & 2.56 & 2.92 & 3.10 & 2.90 \\
\hline
\end{tabular}

Sumber: Tariqullah, Khan \& Habib, Ahmed (2001)

\section{PEMBAHASAN}

\section{Hubungan Resiko dengan Keuntungan}

Pelaku bisnis dalam berinvestasi harus memahami dasar pengambilan keputusan untuk berinvestasi. Hal yang mendasar dalam proses keputusan investasi bagi investor untuk berinvestasi, investor harus mengetahui dasar untuk memutuskan investasi, yakni besarnya imbal hasil, resiko dan hubungan antara imbal hasil dengan resiko adalah hubungan yang searah dan linier. Dengan mengetahui hubungan imbal hasil dan resiko investor dapat memilih aset yang memberikan imbal hasil yang tinggi namun yang resiko nya juga tinggi atau memilih investasi yang resiko rendah namun imbal hasilnya juga rendah.

Konsep hubungan resiko dengan keuntungan dalam investasi sangat erat, sesuai dengan kaedah "al-ghumn alghurm" dan hadis, "al-kharaz bi al dhaman" yaitu tiada keuntungan tanpa resiko" atau dengan kata lain, kesediaan menanggung kerugian diimbangi dengan hak mendapatkan keuntungan.

Asumsi resiko bisnis adalah persyaratan untuk mendapatkan hak atas keuntungan dari modal. Kaedah "alghumn al-ghurm" dan "al-kharaz bi al dhaman" adalah patokan aturan (legalitas) mengenai tingkat imbal hasil atas modal, yang berarti seseorang harus menaggung resiko, jika ada, dan jika ingin mendapatkan keuntungan dari investasinya. Keuntungan harus didapatkan dengan berbagi resiko dan imbal hasil atas kepemilikan melalui penetapan harga barang, jasa, atau hak pemakaian atas barang. (Ayub, 2007) 
Untuk memperoleh keuntungan investor harus menananggung resiko. Hadis dan kaedah diatas menjadi landasan kepada prinsip berinvestasi menurut Islam dimana keuntungan yang ingin diperoleh perlu disertai dengan kesanggupan untuk berbagi resiko. Keuntungan harus didapatkan dengan berbagi resiko dan imbal hasil atas kepemilikan melalui penetapan harga barang, jasa, atau hak pemakaian atas barang.

Kepemilikan tidak dapat dipisahkan dari resiko kerugian yang terkait. Dalam pinjaman, tidak ada hak atas keuntungan kerana kreditor mendapatkan kembali jumlah uang seutuhnya tanpa memandang sifat alamiah penggunaan dananya oleh peminjam mengalami kerugian dalam perdaganga yang dijalankan dengan dana yang dipinjamkan itu.

Dalam perdagangan, selama asetnya tetap berada pada pihak penjual, ia harus menanggung resiko rusaknya barang tersebut; dan ketika ia menjualnya, resiko dialih ke pihak pembeli dan dalam ke penjualan kredit, pihak pembeli harus membayar harga pada waktu yang telah ditetapkan bahkan jika asetnya telah rusak karena alasan apapun.

Sikap investor terhadap resiko akan tergantung kepada preferensi investor terhadap terhadap resiko. Investor yang berani akan memilih resiko yang lebih tinggi karena mengharapkan imbal hasil yang lebih tinggi. Begitu pula sebaliknya, investor yang tidak mau menanggung resiko yang tinggi tidak akan memperoleh imbal hasil yang tinggi. (Tandelilin, 2010)

Dalam perdagangan, selama asetnya tetap berada pada pihak penjual, maka ia harus menanggung resiko rusaknya barang tersebut dan ketika ia menjualnya maka resikonya dialihkan ke pihak pembeli. Resiko bisnis yang terdapat pada akad Shirkah jauh lebih besar dibandingkan resiko pada akad murabahah, salam, ijarah, karena didalam akad shirkah (mudharabah dan musharakah) semua kerugian bisnis harus ditanggung oleh pemilik modal (sahib al mal) dan pelaku bisnis (mudarib). Resiko ini muncul dari kegagalan bisnis dan akibat ketidakpastian dengan kadar keuntungan yang akan dibagi. 


\section{Gambar 2: Hubungan Imbal hasil (Return) dan Resiko pada Sekuritas Konvensional}

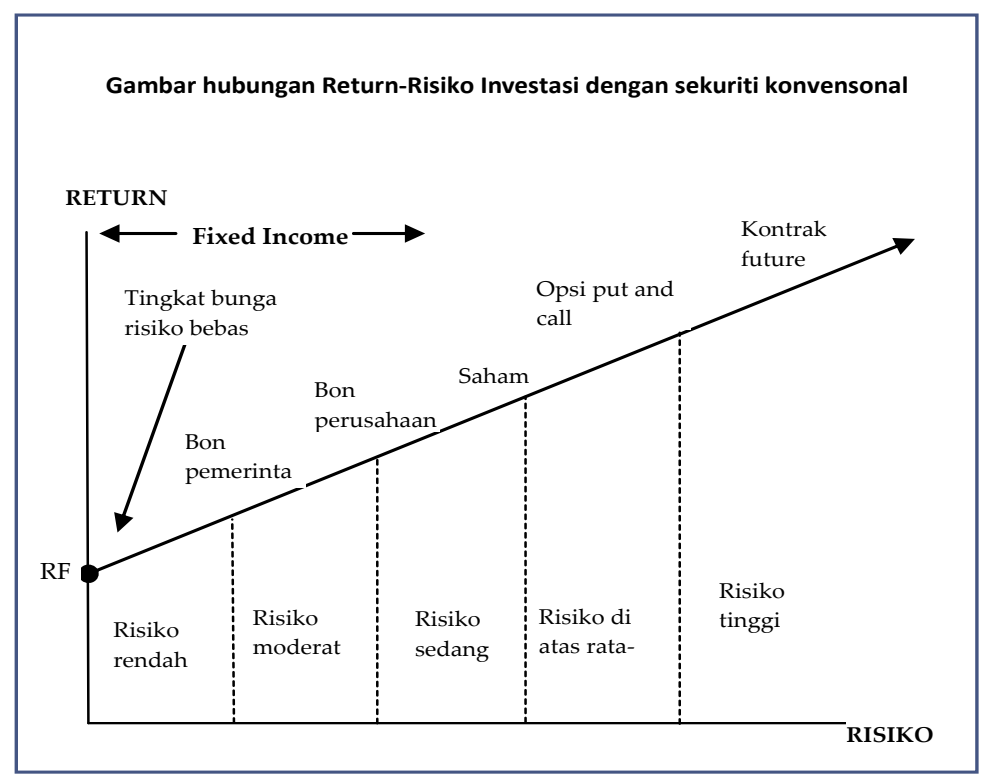

Sumber: Fabozzi (2004)

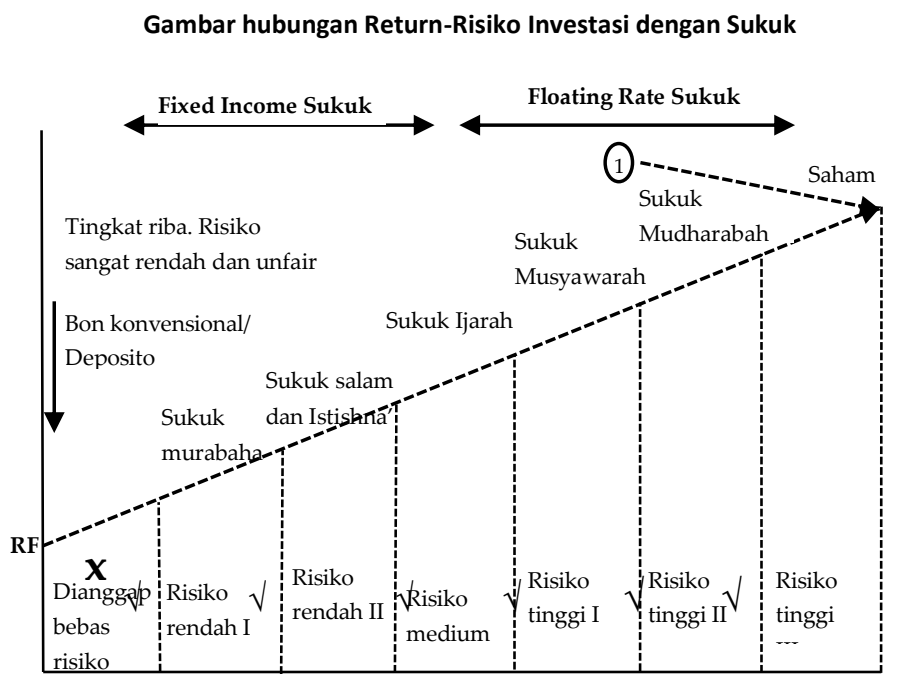

Sumber : Alimin (2010)

Dalam konsep ekonomi tentang teori investasi, bahwa keuntungan berbanding sejajar dengan resiko, semakin besar resiko maka keuntungan yang diharapkan harus lebih besar, dan sebaliknya. Dalam kaedah fiqih dikenal dengan istilah "al-ghunm bil al-ghurm atau al-kharaj bi al-daman”. Istilah lain 
sering disebut high profit high risk, low profit low risk, no risk no gain atau di kenal dengan istilah high risk high return (Raharjo, 2003). Jadi hubungan imbal hasil dan resiko berbanding lurus, artinya semakin tinggi resiko investasi tersebut akan semakin besar imbal hasil yang diharapkan investor.

Pada gambar di atas menunjukkan hubungan antara imbal hasil dan resiko pada berbagai jenis aset yang mungkin bisa dijadikan alternatif investasi. Garis vertikal dalam gambar diatas menunjukkan besarnya imbal hasil dari masing-masing jenis aset, sedangkan garis horizontal memperlihatkan resiko yang ditanggung investor. Titik $\mathrm{Rf}$ adalah return bebas resiko (risk-free rate), $\mathrm{Rf}$ menunjukkan satu pilihan investasi yang menawarkan tingkat imbal hasil sebesar Rf dengan resiko sebesar nol.

Selanjutnya obligasi Negara, diikuti obligasi korporat, selanjutnya saham dan yang memiliki return yang paling tinggi adalah kontrak Futures, namun memiliki resiko yang paling tinggi pula.

Kesimpulan dari hubungan imbal hasil dan resiko memiliki pola hubungan yang searah dan linier. Artinya, semakin tinggi resiko suatu aset, semakin tinggi pula tingkat return dari aset tersebut yang dikenal dengan istilah high risk high return, demikian sebaliknya. (Tandelilin, 2012)

Para fuqaha tidak membolehkan berinvestasi pada obligasi konvensional karena mengandung unsur bunga dan mempresentasikan hutang dengan bunga. Oleh karena itu obligasi yang di tawarkan harus mengikuti kaedah-kaedah syariah, dengan cara antara lain (Syhatah dan Fayyadh, 2004):

- Penghapusan bunga dan mengalihkannya ke instrumen investasi yang mengikuti pada prinsip dalam keuntungan dan dalam kerugian serta tunduk pada kaedah "al-ghunm bi al-ghurm" (keuntungan atau penghasilan itu berimbang dengan kerugian yang ditanggung). Dalam hadis menggunakan istilah "al-kharaz bi al-daman".

- Penghapusan syarat jaminan atas kembalinya harga obligasi dan bunga sehingga menjadi seperti saham biasa dan pengalihan obligasi ke saham biasa.

- Pengalihan obligasi ke saham biasa.

\section{KESIMPULAN}

Secara umum konsep laba, rugi dan resiko yang dihadapi keuangan konvensional dengan keuangan syariah hampir sama, yaitu resiko keuangan, resiko bisnis, resiko treasuri dan resiko tata kelola (governance risk). Namun pada keuangan syariah menghadapi resiko kepatuhan dengan prinsip syariah.

Konsep untung dan rugi dalam Al Quran menjadi lebih luas karena dimensi waktunya dari dunia sampai akhirat, bukan berkaitan dengan jual beli barang atau investasi pada aset saja. Adapun pola hubungan imbal hasil dengan resiko yang dihadapi institusi keuangan konvensional dengan syariah hubungannya searah dan linier. Oleh sebab itu, investor dapat memilih instrumen investasi yang imbal hasil tinggi dengan resiko tinggi atau investasi yang resiko rendah dengan imbal hasil yang rendah pula. Namun demikian, tujuan utama investor menginvestasi dananya untuk memperoleh imbal hasil (return) yang tinggi, jadi semakin besar imbal hasil maka semakin menarik investasi tersebut.

\section{DAFTAR PUSTAKA}

Alimin. 2010. Aplikasi Pasar Sukuk dalam Perspektif Syariah (Studi Analisis Kesesuaian Syariah terhadap Aplikasi Pasar Sukuk Domestik dan Global). Disertasi 
Pascasarjana Universitas Islam Negri Syarif Hidayahtullah. Jakarta.

Ayub, Muhammad. 2007. Understanding Islamic Finance. Penerjemah: Aditya wisnu Pribadi. PT. Gramedia Pustaka Utama. Jakarta.

Dusuki, Asyraf Wajdi. 2009. Principles and Application of Risk Management and Hedging Instruments in Islamic Finance, di petik dari : www.asyrafwajdi.com.

Fabozzi, Frank. J. 2004. Investment Fifth Edition. Prentice Hall. New York.

Iqbal, Zamir and Mirakhor, Abbas. 2006. An Introduction to Islamic Finance- Theory and Practice, Handbook. Wiley Finance Editions, John Wiley \& Sons, Inc.. New Jersey.

Khan, Tariqullah \& Habib, Ahmed. 2001. Risk Management An Analysis of Issues in Islamic Financial Industry. Islamic Research and Training Institute. Islamic Development Bank Group. Jeddah.

M. Hanafi, Mamduh. 2006. Manajemen Resiko. UPP STIM YKPN. Yogyakarta.

Raharjo, Sapto. 2003. Panduan Investasi Obligasi. Gramedia. Jakarta.

Sholihin, Ahmad Ifham. 2010. Buku Pintar Ekonomi Syariah. Gramedia Pusaka Utama. Jakarta.

Syhatah, Husein dan Fayyadh, Athiyyah. 2004. Bursa Efek- Tuntunan Islam Dalam Transaksi di Pasar Modal, Penerjemah : A. Syakur. Pustaka Progressif.

Syhatah, Husein. 2001. Pokok-Pokok Pikiran Akuntansi Islam. Penerjemah : Husnul Fatarib. Akbar. Jakarta.
T. Sunaryo, 2007. Manajemen Resiko Finansial. Salemba Empat. Jakarta.

Tandelilin, Eduardus. 2010. Portofolio dan Investasi Teori dan Aplikasi. Kanisius. Yogyakarta. 